\title{
Factors Affecting Labor Productivity of Small Manufacturing Industry
}

\author{
Mohammad Rizal*, Sulton Sholehuddin \\ Faculty of Economics and Business, Islamic University of Malang, Malang \\ *MohammadRizal@unisma.ac.id
}

\begin{abstract}
The industrial sector is one of the sources of income in Indonesia, although basically the state of industry in Indonesia still has many problems including regarding low-educated labor, limited capital and uneven income distribution. Malang City is one of region in East Java with a largest source of income from the manufacturing industry sector. The variables observed in this study are education and gender issues on productivity. This study uses primary data obtained through questionnaires and analyzed by multiple regression models. The results show that: 1) Education influences the labor productivity of small-scale manufacturing industries in Malang City; 2) Gender has a positive and significant effect towards labor productivity in small-scale manufacturing industries in Malang City; 3) Male labor productivity is higher than female labor productivity.
\end{abstract}

Keywords : Labor, Manufacturing Industry, Productivity

\section{INTRODUCTION}

Employment is a very basic aspect of human life because it covers the social and economic dimensions. The important goal in economic development is the provision of sufficient employment to pursue the growth of the workforce, which the growth of workforce is faster than the growth of employment opportunities. The problem of employment is an important problem in the macro economy because labor is one of the factors of production besides capital and technology.

In accordance with the result of research that labor has a positive and significant effect on economic growth. This is mainly due to the fact that workers who are classified into the workforce working in the economic sector are the driving factors of production the regional economy, besides that the large number of workers with high productivity is one of the positive drivers in accelerating economic growth (Putri, 2014). Education is needed to get quality human resources because education is considered capable of producing high-quality labor that has a modern mindset and way of acting. Such human resources are expected to be able to drive the wheels of development going forward.

Education is positioned as a means for improving welfare through the use of existing employment opportunities and reflects the level of intelligence or achievement of formal education of the population because the higher the level of education of a person, the higher the work ability or productivity of a person at work (Sanmut, 2017).

Besides education, gender can indicate a person's level of productivity which will affect income. Basically, male productivity levels are higher than women. This is influenced by factors possessed by 
women such as physical strength, in working tend to use feelings or biological factors such as having to take time off when giving birth. But in certain circumstances sometimes women's productivity is higher than that of men, for example work that requires precision and patience. In jobs that require a female production process, they are usually more thorough and patient (Sasmitha Ketut and Ayuningsasi, 2017)

The production growth of micro and small manufacturing industries in East Java in the fourth quarter of 2017 (q to q) grew by $2.20 \%$. The production growth of micro and small manufacturing industries in East Java in the fourth quarter of 2017 (y to y) grew by 6.40\% (BPS, 2017), which made East Java one of the driving forces of industry in Indonesia. Malang City is one of the cities in East Java that contributes large revenues from the industrial sector, one of which is the manufacturing industry. Manufacturing Industry is an economic activity that carries out activities to change a basic item mechanically, chemically, or by hand so that it becomes finished or semi-finished goods, a higher value item, and is closer to the end user (BPS, 2017).

The importance of the role of small industries in the process of Indonesia's economic development, especially Malang City as a destination city in East Java, related to the condition of Indonesia which has a low educated workforce, abundant resources, limited capital and uneven income distribution, so it is very close has to do with the basic properties of small industries. The role of small industries can be seen from two aspects, namely the role of labor absorption and the role of export value. Based on statistical data (BPS, 2017), it can be seen that the GRDP of Malang City is supported by industrial activities, in which the contribution to the formation of its Gross Domestic Product reaches 28.92\%, especially in the manufacturing industry. From the results of a survey of small and medium industries, the number of industrial companies in 2016 were 646 companies with a number of small and medium-sized workers totaling 13,302 people. Total income from small and medium industry activities during 2016 was Rp255,759,234,000. Seeing the BPS report data automatically industrial activities in Malang City contribute significantly and make Malang City as one of the largest manufacturing industries.

Based on the description, this research will discuss the factors that affect a small industry in Malang City.

\section{Labor Productivity}

Siagian (2014) explained that work productivity is the ability to produce goods/ services from various resources and capabilities possessed by each worker/ employee. Generally, productivity can be interpreted as the ability to improve employee work outcomes in terms of the resources possessed by each individual. According to Jackson in (Agustin: 2014), productivity is interpreted as increasing work outcomes that are influenced by the ability of employees (input) and produce an item or service (output). Lexley and Yukl in Edyun (2012), state that work productivity of organization employee plays a very important role. Because the growt of the organization is very dependent on work productivity of their employees. An employee who performs certain types of work well, certainly give good results for organization.

\section{Industry}

Industry is an effort to improve the welfare of the population. Industrialization is also inseparable from efforts to improve the quality of human resources and the ability to utilize natural resources optimally. Based on Law No.5 of 1984 on Industry, industry is an economic activity that manages raw materials, raw materials, semi-finished goods, and/or finished goods into goods with a higher value for use including design activities and industrial engineering. From a geographic point of view, industry as a system, is a combination of physical sub 
systems and human sub-systems (Sritomo: 2003).

\section{Education}

According to Law No.20 of 2003 on Education, education is a conscious and planned effort to create a learning atmosphere and learning process so that students actively develop their potential to have religious spiritual strength, self-control, personality, intelligence, noble character, and skills needed by themselves, society, nation and country. According to H. Fuad Ihsan (2005), explains that in a simple sense and generally the meaning of education as "human effort to grow and develop the potential of carrying out both physical and spiritual in accordance with the values that exist in society and culture". Efforts are made to instill these values and norms and pass on to the next generation to be developed in life and life that occur in a process of education as a human effort to preserve life.

\section{Gender}

As quoted in the book Friedman and Schustack (2008; 79), there are several areas where we can find gender differences that are reliably related to psychological abilities, especially in areas that involve thinking, perception, and memory abilities. Generally, men (from childhood to adulthood) show better spatial abilities, while women (from childhood to adulthood) show more advanced verbal abilities regarding thinking, perception, and memory abilities. In general, men (from childhood to adulthood) show better spatial abilities, while women (from childhood to adulthood) show more advanced verbal abilities. Gender is very closely related to small businesses related to people's economic activities with equitable development for women and men, isocial justice, economic efficiency, and efforts to encourage regional development. This goal can be achieved through strategies based on conditions, needs, and potential.
Refering to the research problems above, the desired objectives through this research are: 1) whether education has an effect on labor productivity in small manufacturing industries in Malang City, 2) whether gender has effect on labor productivity in small manufacturing industries in Malang City.

\section{METHOD}

The method of data analysis in this study is multiple linear regression analysis. In addition to multiple linear regression, this study also uses dummy regression. Another name for dummy regression is regression category. This regression uses qualitative predictors (those that are not dummy are called quantitative predictors). Dependent variables basically can not only be influenced by quantitative independent variables, but also made possible by qualitative variables. The qualitative variable must be quantified in its attributes.

The equation model can be described as follows:

$$
\begin{aligned}
& \mathrm{Y}=f(X 1, X 2) \\
& \mathrm{Y}=\alpha_{0}+\alpha_{1} X_{1}+\alpha_{2} X_{2} \\
& \text { Information } \\
& \mathrm{Y} \quad=\text { Labor Productivity } \\
& \mathrm{X}_{1} \quad=\text { Education } \\
& \mathrm{X}_{2} \quad=\text { Gender } \\
& \alpha_{0} \quad=\text { Constants }
\end{aligned}
$$

The population in the study is a small-scale manufacturing industry workforce in Malang City. Sampling uses the accidental sampling method that is random sampling and obtained a number of samples of 100 manufacturing industries in Malang.

\section{RESULT AND DISCUSSION Result}

Malang City is a city located in East Java Province, Indonesia. Malang City is located $90 \mathrm{~km}$ south of Surabaya City, and is the second largest city in East Java after the City of Surabaya. Malang City is on a plateau so the air feels cool. Malang City is one part of the regional unity known as Malang Raya 
along with Batu City, and Malang Regency. Table 3. Results of Estimated Productivity of Malang City is known as an education city, Manufacturing Small Industry Labors in Malang industrial city, and tourism city. City

\begin{tabular}{lcc}
\multicolumn{3}{l}{ Table 1. Distribution of Respondents by Education } \\
\hline \multicolumn{1}{c}{ Education } & $\begin{array}{c}\text { Number of } \\
\text { Respondents }\end{array}$ & Percentage (\%) \\
\hline Elementary school & 15 & 15,00 \\
Junior High School & 21 & 21,00 \\
Senior High School & 47 & 47,00 \\
Diploma Degree 1 & 5 & 5,00 \\
Diploma Degree 3 & 4 & 4,00 \\
Bachelor & 8 & 8,00 \\
Total & 100 & 100,00 \\
\hline
\end{tabular}

Source: Primary Data Processed, 2018

From the research that has been done, it can be seen that the average education of workers in small manufacturing industries mostly shows SMA respondents (47\%). Followed by respondents with SMP education (21\%), and the least respondents were respondents who were educated D3 $(4 \%)$.

Table 2. Distribution of Respondents by Gender

\begin{tabular}{lcc}
\hline \multicolumn{1}{c}{ Gender } & $\begin{array}{c}\text { Number of } \\
\text { Respondents }\end{array}$ & Percentage (\%) \\
\hline Male & 63 & 63,00 \\
Female & 37 & 37,00 \\
Total & 100 & 100,00 \\
\hline Source: Primary
\end{tabular}

Source: Primary Data Processed, 2018

It can be seen at table 2 that the number of respondents $63 \%$ male and $37 \%$ female. This is related to the responsibility of married men to support their families to meet household needs. The large number of male labors who work in small manufacturing industries in the city of Malang is because male labors have more energy than female so that men's working hours are more than women who can produce more than female labors.

\begin{tabular}{lccc} 
Variable & Coefficient & t-statistics & Prob \\
\hline Constants (c) & 87,753 & 0,009 & 0,993 \\
Education & 4656,608 & 4,796 & 0,000 \\
Gender & 15543,913 & 2,610 & 0,014 \\
& & F-Statistik $=$ & F(Sig) $=$ \\
n = 100 & R2 = 0,597 & 22,969 & 0,000 \\
\hline \multicolumn{2}{l}{ Source: Primary Data Processed, 2018 }
\end{tabular}

Source: Primary Data Processed, 2018
Based on data analysis on table 3, the value of $\mathrm{R} 2=0.597$ indicates that productivity (the value of production divided by the number of working hours) can be explained $59,7 \%$ by education and gender.

The sig F-statistic value of 0,000 $(<5 \%)$ indicates that education and gender factors simultaneously have a significant effect on the labor productivity of small manufacturing industries in Malang City based on the value of their production.

The results of statistical test show that the education variable has a positive and significant effect on labor productivity in small-scale manufacturing industries in Malang City (sig $\mathrm{t}=0,000<5 \%$ ). The positive effect means that higher the education of labor the higher the labor productivity.

The results of statistical test also show that gender variables have a positive and significant effect on labor productivity variations in Malang City. ( $\operatorname{sig} \mathrm{t}=0,014<$ $5 \%$ ). This means that there is a difference between male labor and female labor towards labor productivity. Based on this description shows that male labor productivity is more influential than the productivity of female labor.

\section{Discussion}

The results of the research show that the effect of education on labor productivity in small manufacturing industries in Malang City is positive and significant. That results related with the research of Teddy Adhadika (2014), that generally people who have high formal education will have broad insights. High awareness of the importance of 
productivity will encourage related workforce to take productive action.

Partially, education significantly affects the productivity of small-scale manufacturing industries. The existence of a significant effect between education and productivity indicates that productivity is influenced by education. The higher the level of education of a person, the higher the productivity of his work. It is because education makes the person have a better mindset, views and motivations. A good mindset, advanced outlook and high motivation will drive the person's performance. Good performance will increase productivity. Conversely, if someone's education is low then the mindset will also be low, low views, low morale, and motivation is not good. Therefore, all of this will have an impact on low performance. This low performance will reduce productivity.

The results of the research findings indicate that gender differences in labor productivity in small manufacturing industries in Malang City are positive and significant. This shows that there are differences in gender productivity between male labor and female labor. Male labor productivity in small manufacturing industries in Malang City is more effective or more productive than female labors. Gender labor in small manufacturing industries in Malang City has more male labors than female labors. In line with the level of male work participation is always higher than the level of women's work participation because men are considered the main breadwinner for the family, so male labors are usually more selective in choosing jobs that are in line with their aspirations both in terms of income and position compared female workers. This result is related with the research of Hanna Rianita (2016), that gender factors determine the level of participation and productivity of a person at work. Labor basically cannot be distinguished based on gender. Basically women and men are very different from both their behavior and personality.

\section{Conclution}

Based at the results described above, it can be concluded that: 1) Education effect labor productivity of small manufacturing industries in Malang City because the higher the level of education of a person, the higher the productivity of his work. Education makes the person have a better mindset, outlook and motivation. A good mindset, advanced outlook and high motivation will drive the person's performance. Good performance will increase productivity; 2) Gender has a positive and significant effect on labor productivity in small-scale manufacturing industries in Malang City. It means that there is a difference in productivity between male labor and female labor. Gender determines the level of participation and productivity of a person at work; 3) Male labor productivity is higher than female labor productivity. Labor basically cannot be distinguished based on gender. But generally men will be more productive for jobs that rely on physical strength. The suggestion in this study is that small-scale industrial entrepreneurs in Malang City should provide training for female workers because the results in this study state that female labor productivity is low.

\section{REFERENCES}

Adhadika Teddy, 2014. Analisis FaktorFaktor yang Mempengaruhi Produktivitas Tenaga Kerja Industri Pengolahan di Kota Semarang (Studi Kecamatan Tembalang dan Kecamatan Gunung Pati). Volume 3, Nomor 1, Tahun 2014, Halaman 1-13. http://ejournal-s1.undip.ac.id/ index.php/jme Diponegoro Journal of Economics.

Agustin, Ririn Pratiwi. (2014) Hubungan antara produktivitas kerja terhadap pengembangan karir pada karyawan pt. Bank mandiri tarakan: ejournal psikologi, 2014, 2 (1): 24-40

Badan Pusat Statistik Provinsi Jawa Timur. 2017. Jawa Timur Dalam Angka 2017. 
BPS Provinsi Jawa Timur. Tersedia di www.jatim.bps.go.id, diakses pada 1 Februari 2018.

Badan Pusat Statistik Kota Malang. 2017. Kota Malang Dalam Angka 2017. BPS Provinsi Jawa Timur. Tersedia di www.jatim.bps.go.id, diakses pada 1 Februari 2018.

Friedman, H. S.\& Schustack, M. W. (2008). Kepribadian Teori Klasik dan Riset Modern Jilid 1. Jakarta: Erlangga.

Edyun, Neti. (2012) Hubungan antara stres kerja dengan produktivitas kerja karyawan. Jurnal Universitas Muhammadiyah, Surakarta

Fuad, ihsan. 2005. Dasar-dasar Pendidikan. Jakarta: PT Rineka Cipta.

Putri, Phany Ineke. (2014). Pengaruh Investasi, Tenaga Kerja, Belanja Modal, dan Infrastruktur Terhadap Pertumbuhan Ekonomi Pulau Jawa. JEJAK Journal of Economics and Policy, 7 (2): 100-202.

Rianita Hanna, 2016. Pengaruh Pendidikan, Pengalaman Kerja, dan Jenis Kelamin terhadap Produktivitas Kerja Karyawan Bagian Produksi CV. Karunia Abadi Wonosobo. Universitas Negeri Yogyakarta.

Ria Sasmitha, Ni Putu. 2017. FaktorFaktor yang Mempengaruhi Pendapatan Pengrajin pada Industri Kerajinan Bambu di Desa Belega Kabupaten Gianyar. Denpasar.

Sanmut, Miss Nichakorn, 2017. Analisis Faktor-Faktor yang Mempengaruhi Pertumbuhan Ekonomi di Thailand. Yogyakarta.

Undang-Undang No 20 Tahun 2003 tentang Sistem Pendidikan Nasional. Jakarta: Depdiknas.

Undang-Undang Nomor 5 Tahun 1984 Tentang Perindustrian (Lembaran Negara Republik Indonesia No.22, Tambahan Lembaran Negara No.3274). 